\title{
INTERNET

\section{Development of Web-based Scientific Research Projects (SRP) Management Information System for Universities}

\section{Üniversiteler için web tabanlı bilimsel araştırma projeleri (BAP) yönetim bilgi sistemi geliştirilmesi}

\author{
Abdulkadir YALDIR 1, akyaldir@pau.edu.tr
}

\author{
Received/Geliş Tarihi: 10.03.2016; Accepted/Kabul Tarihi: 27.04.2016
}

doi: $10.5505 /$ iuyd.2016.41736

Scientific Research Projects (SRP) are theoretical or practical projects that can contribute to science, economy or art at national or international level. The process of coordinating entire procedures to receive project applications, evaluating them and ensuring the follow-up of the projects in case of their acceptance is a time consuming and complex process. This process is usually carried out by a SRP Coordination Unit at the universities. In the scope of this study, a web-based management information system has been developed to ease this workload in project procedures, to eliminate procedure complexities, to follow the processes required by the projects in a transparent manner through a system and to ensure a more secure storage of the data. In addition to SRP Coordination Unit supported projects, external projects, mentor/mentee applications and Revolving Fund Directorate (RFD) supported projects were also included in the scope of management information system. By means of this system, application, evaluation and budget processes can be managed and the projects can be monitored instantly and required operations can be performed on purchase and expenditure items. At the same time, projects can be assessed in terms of academic performance indicators during evaluation process according to certain criteria such as accepted, completed etc., and the results can be reported to senior management. As a result, a multidimensional project management information system has been designed, put into practice and it has been intended to guide other universities through experiences acquired during the process.

Keywords: Scientific research projects (SRP), Project management information system, Academic performance indicators

Jel Codes: O32, L86.
Bilimsel Araştırma Projeleri (BAP) ulusal veya uluslararası düzeyde bilime, ekonomiye veya sanata katkı să̆layabilecek teorik ya da uygulamal projelerdir. Proje başvurularının alınması, değerlendirilmesi ve kabul edilmesi durumunda projenin izlenmesini săglayarak tüm süreci koordine etme işlemi zaman alıcı ve karmaşık bir süreçtir. Bu süreç üniversitelerde genellikle BAP Koordinasyon Birimi tarafindan yürütülür. Çalışma kapsamında proje işlemlerindeki bu iş yükünü hafifletmek, iş karmaşıklı̆̆ını gidermek, projelerin gerektirdiğgi süreçleri sistem üzerinden şeffaf bir şekilde takip etmek ve verilerin daha güvenli tutulmasın sağlamak amacılla web tabanlı yönetim bilgi sistemi geliştirilmiştir. BAP Koordinasyon Birimi destekli projeler yanında, dış kaynaklı projeler, mentor/mentee başvuruları ve Döner Sermaye Müdürlüğ̈̈ (DSM) destekli projeler de yönetim bilgi sistemi kapsamına alınmıştır. Sistem sayesinde, başvuru, değerlendirme ve bütçe işlemleri yönetilebilmekte ve projeler anlik olarak izlenerek alım ve harcama kalemleri üzerinde istenen işlemler yapılabilmektedir. Aynı zamanda, projeler akademik performans göstergeleri için değerlendirme aşamasında, kabul edilen, tamamlanan vb. kriterlere göre ölçülebilmekte ve sonuçlar üst yönetime raporlanabilmektedir. Sonuç olarak üniversiteler için çok boyutlu proje yönetim bilgi sistemi tasarlanmış, uygulamaya alınmış ve edinilen tecrübeler dahilinde diğer üniversitelere yol göstermek amaçlanmıştır.

Anahtar Kelimeler: Bilimsel araştırma projeleri (BAP), Proje yönetim bilgi sistemi, Akademik performans göstergeleri

Jel Kodları: O32, L86.

\footnotetext{
${ }^{1}$ Asst. Prof. Dr., Pamukkale University, Department of Management Information System
} 


\section{INTRODUCTION}

Scientific Research Projects (SRP) are studies, whose purpose, scope, duration, budget, special requirements, in-kind and/or in-cash support amounts to be provided are determined by a contract, and they are carried out according to scientific principles to produce new information or resolve technological/social problems (Official Gazette, 2002). SRP Coordination Units at the universities, on the other hand, are established to support research projects, coordinate and encourage project works conducted with cooperation of national and international, public or private organizations, follow any type of financial and academic processes with respect to these projects (Web-1; Web-2). Ensuring efficient use of public resources allocated for scientific researches cannot be achieved with the activities of supervisory authorities only. Therefore, it is important for institutions such as universities to use these resources in the name of public to manage the entire process effectively by using information systems and take necessary measures. With the developed management information system, it has been intended to ease unnecessary workload performed manually in the SRP Coordination Unit, eliminate procedure complexities, ensure follow-up of the processes required by the scientific projects in a transparent manner through a system and ensure storage of the data in a more secure and meaningful format.

When the relevant literature has been reviewed, it has been seen that although there are studies regarding the analysis of research projects carried out at universities (Leonard, 2015; Altunay \& Tonbul, 2015), evaluation of scientific research projects with various methods (Hou et al., 2015; Nastase \& Badea, 2015), application of information management methodologies in scientific research projects (Mezghani et al., 2016), proposed viewpoint to solve campus scientific research security issues such as authentication, access control, communications security and digital signatures (Wang at al., 2010) and ontology-based semantic data retrieval for university scientific research information in the web (Zhai at al., 2012), no studies were found where management information systems developed for scientific research projects are examined or outputs acquired as a result of monitoring and coordination of such systems are shared.

While universities are institutions where technology is used most commonly, it cannot be said that they can provide desired productivity in web-based applications (Tecim \& Gökşen, 2009). Therefore, to make a contribution in this area, an application has been designed and developed at Pamukkale University (PAU), which has been integrated with the existing information system of the university, whereby project applications, their evaluation and budget operations have entirely been performed and followed in the web environment. In addition, in order to compile indicators required for Entrepreneurial and Innovative University Index of Turkey (Web-3), external projects, mentor/mentee applications and Revolving Fund Directorate (RFD) supported projects have also been included in the scope of this management information system.

As a result of reviews, it has been seen that the existing applications on the market do not support external projects, mentor/mentee applications and RFD supported projects; moreover, the related software vendors do not provide any services to give such supports and those applications were found to be inadequate in the integration with other modules used at universities. At the same time, there are many studies indicating the risk of 
purchasing third-party software (Uçar \& Bilgen, 2013; Soares et al., 2014). Therefore, in order to prevent both dealing with integration issues by purchasing third-party software and also making extra payments under annual maintenance contracts, it was decided to develop a custom made application within the requirements. The application has been developed and put into practice as an integrated module of the existing information system as a joint project under the leadership of PAU Information Technology Department with the cooperation of SRP Coordination Unit and Pamukkale Technocity Technology Transfer Office (TTO) authorities.

The application is based on Waterfall Model (Arifoğlu \& Doğru, 2001), which is a traditional software development model for this kind of projects where the requirements and scope are fixed. Primarily, users were interviewed and analysis works were initiated, examining necessary regulations and directives. Design works following the analysis works were evaluated in the meetings with the users and software development and coding phase was started according to their final versions.

The application was coded in Visual Studio environment, using ASP.NET web application platform. SQL Server was used as Database Management System, and SQL Server Reporting Services were used for reports. At the end of the software development phase, necessary tests were conducted, considering all possible user behavior and data types, and training videos in the form of visual instruction manuals were prepared for users. The application has been actively used since September 2015, and required support and maintenance has been provided by PAU Information Technology Department.

Within the scope of this study; coordinated project types, SRP general process and SRP coordination process are described in the second part. In the third part, requirement engineering studies within the scope of system analysis and design are briefly discussed and general context diagram and relational database model, created according to acquired conclusions, are included. In the fourth part, achievements obtained through the application and features that can be added to the application in the future are indicated.

\section{SRP COORDINATION PROCESS}

The project types that are coordinated in the application are as follows:

- Beginner Level Research Projects

- Master's Thesis Projects

- PhD Thesis Projects

- Institutional Infrastructure Projects

- Medical Dissertation Projects

- Fast Support Projects

- Congress Participation Projects

- Publication Support Congress Participation Projects

The General Process of SRP covering the above projects is shown in detail Figure 1. 


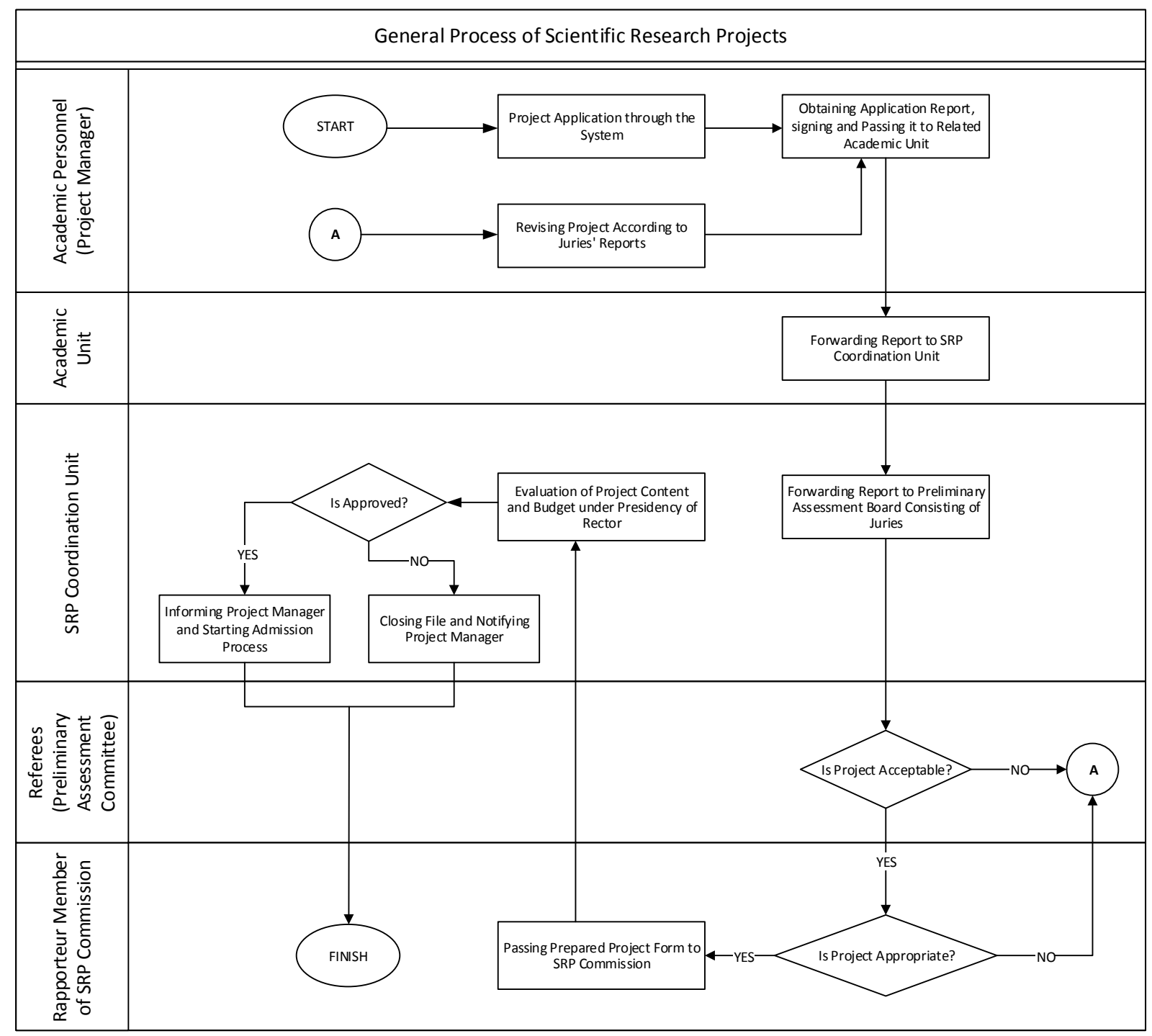

Figure 1. General Process of Scientific Research Project

As seen in Figure 1, the project process starts as soon as the Project Manager who will be managing the project makes a project application through the system. In this context, the completed application file is downloaded from the system by the project manager, transmitted with wet signature through the relevant academic unit to the SRP Coordination Unit. If the project is not found acceptable by the Preliminary Assessment Board, consisting of juries, it is returned to the project manager for necessary adjustments. If the project is found acceptable, it is sent to a rapporteur that is a member of the SRP commission. If the project is not approved by the rapporteur at this stage, the project manager is asked to make necessary corrections according to the provided report. If the project is approved, the rapporteur passes the approval report to the SRP Coordination Unit. The SRP Commission under the presidency of the Rector evaluates the content and the budget of the project. The project manager is notified of those projects that are not approved as a result of this evaluation process and the file is closed. The project manager is also notified of those projects that receive approval and the project approval process is completed. 
For the approved projects, coordination process starts in the subsequent steps and necessary purchases, if any, for the project are determined and purchasing process is carried out. After the supply of necessary materials, the project is virtually initiated by the project manager and SRP Coordination Process starts for follow-up of the project in the name of the institution. The SRP Coordination Process is shown in detail in Figure 2.

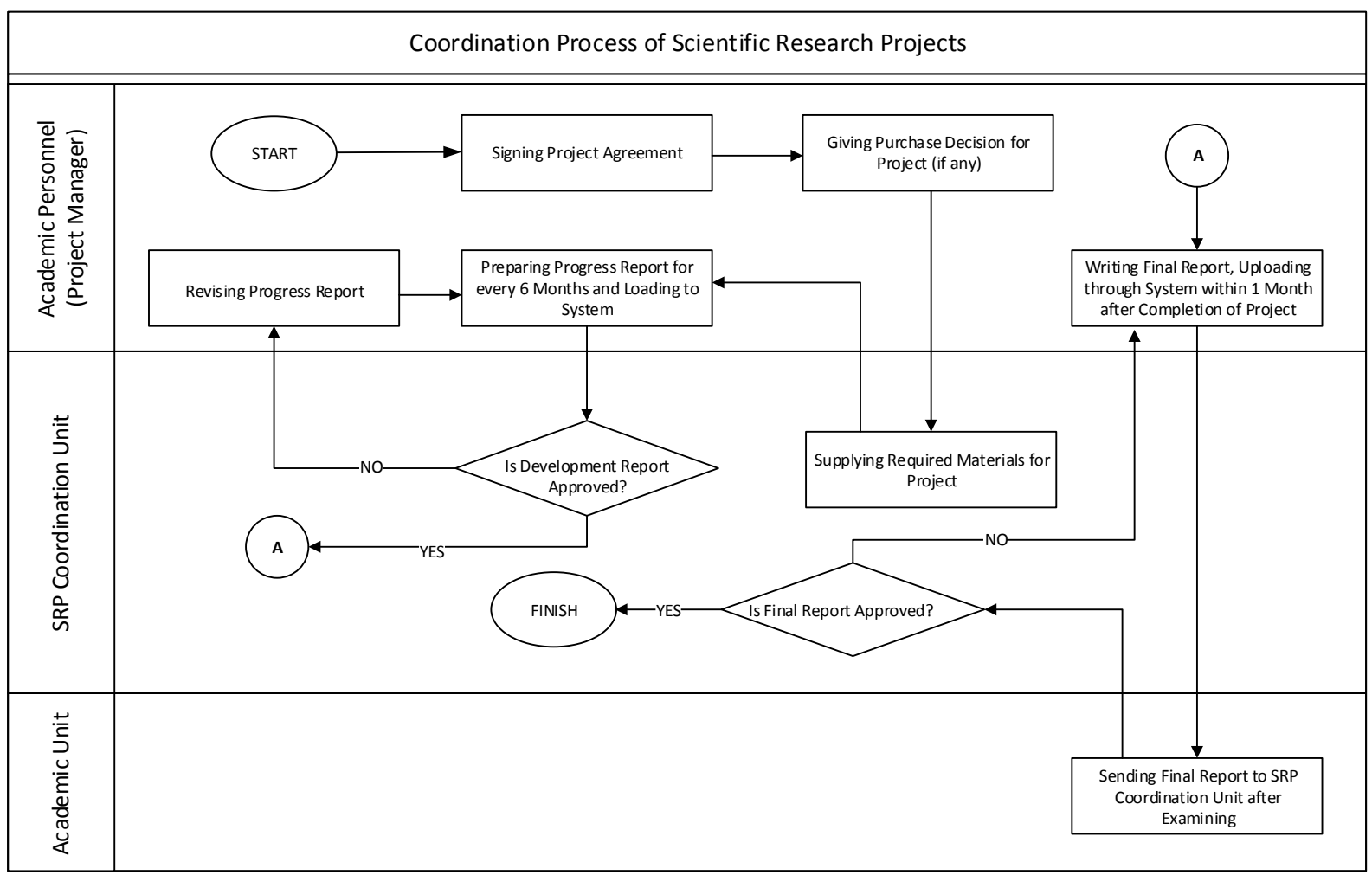

Figure 2. Scientific Research Project Coordination Process

Throughout the project period, a progress report is prepared every six months by its project manager as a regulatory requirement and it is uploaded through the system. The project manager also passes the progress report with a cover letter and a wet signature over the related academic unit to the SRP Coordination Unit. If the report examined by the SRP Commission does not receive approval, the project manager is asked to revise the progress report. The project manager writes a final report within one month after completion of the project at the latest and again uploads through the system. The project manager also sends it with a wet signature over the related academic unit to the SRP Coordination Unit and the process is completed.

\section{SYSTEM ANALYSIS AND DESIGN}

Many difficulties have been encountered during the process of analysis and design works performed for the SRP Management Information System. The most important difficulty, on the other hand, is classic resistance and mistrust users harbor against information systems. In order to overcome these difficulties, interactive meetings have been held with the users within the context of possible scenarios, introducing user-friendly interface prototypes; consequently, positive feedback have been received. Still, it has occurred that some intermediary processes that were not mentioned previously have been involved in the 
design and development process of the application and the design process had to be revised to cover them.

The developed SRP Management Information System includes all regular academic personnel of the Pamukkale University, the Pamukkale Technocity TTO personnel, the SRP Coordination Unit personnel, the RFD personnel and system administrators. General Context Diagram for the SRP Management Information System, compatible with Structured Systems Analysis \& Design Methodology (SSADM) (Britton \& Doake, 2005) is given in Figure 3.

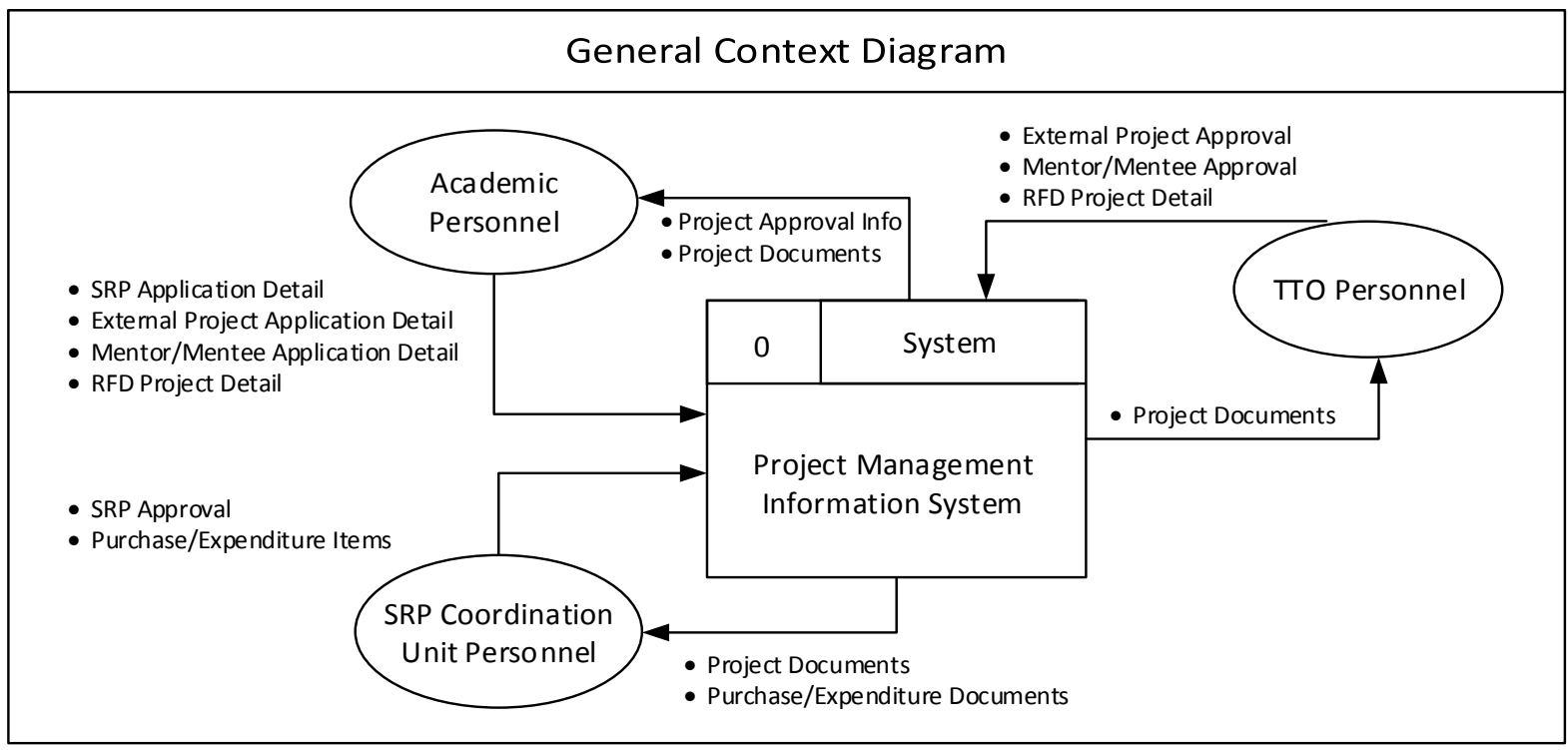

Figure 3. SRP Management Information System General Context Diagram

As seen in Figure 3, the academic personnel can make project applications over the system, update these projects within specified periods and upload related project files to the system. Furthermore, a mentor/mentee application system has been included in the system and activated by creating a pool for matching the personnel with the purpose of allowing academic personnel experienced in project software to support other personnel. On the other hand, external and RFS supported project application can also be carried out through the system. The SRP applications go through an approval process according to the content of the projects, which are evaluated by the SRP personnel based on necessary regulations within specified period. Those approved projects can be followed by project managers through the system.

Procedures based on the entity roles of the Academic Personnel, the TTO Personnel and the SRP Personnel within the General Context Diagram are shown in detail in Figure 4. 


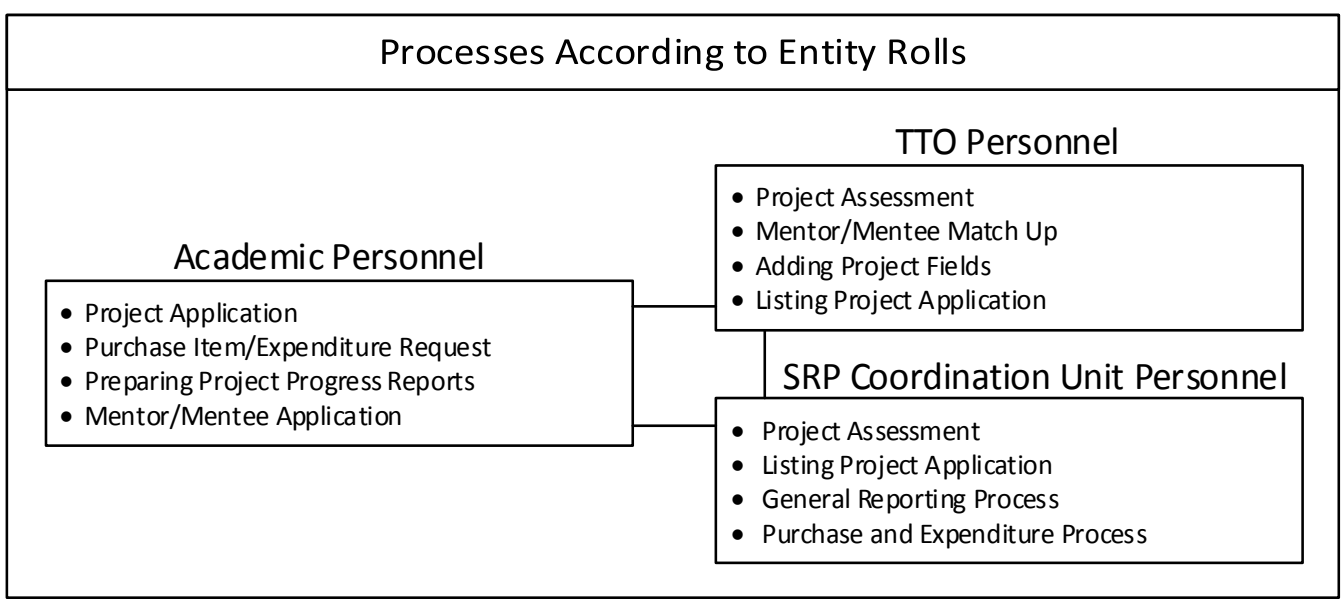

Figure 4. SRP Management Information System Procedures Based on the Entity Roles

A relational database model, normalized up to the third normal form level, has been established for application and associated with the current database model of the university. Entity-Relationship (E-R) diagram for the relational database model established for application is shown in detail in Figure 5.

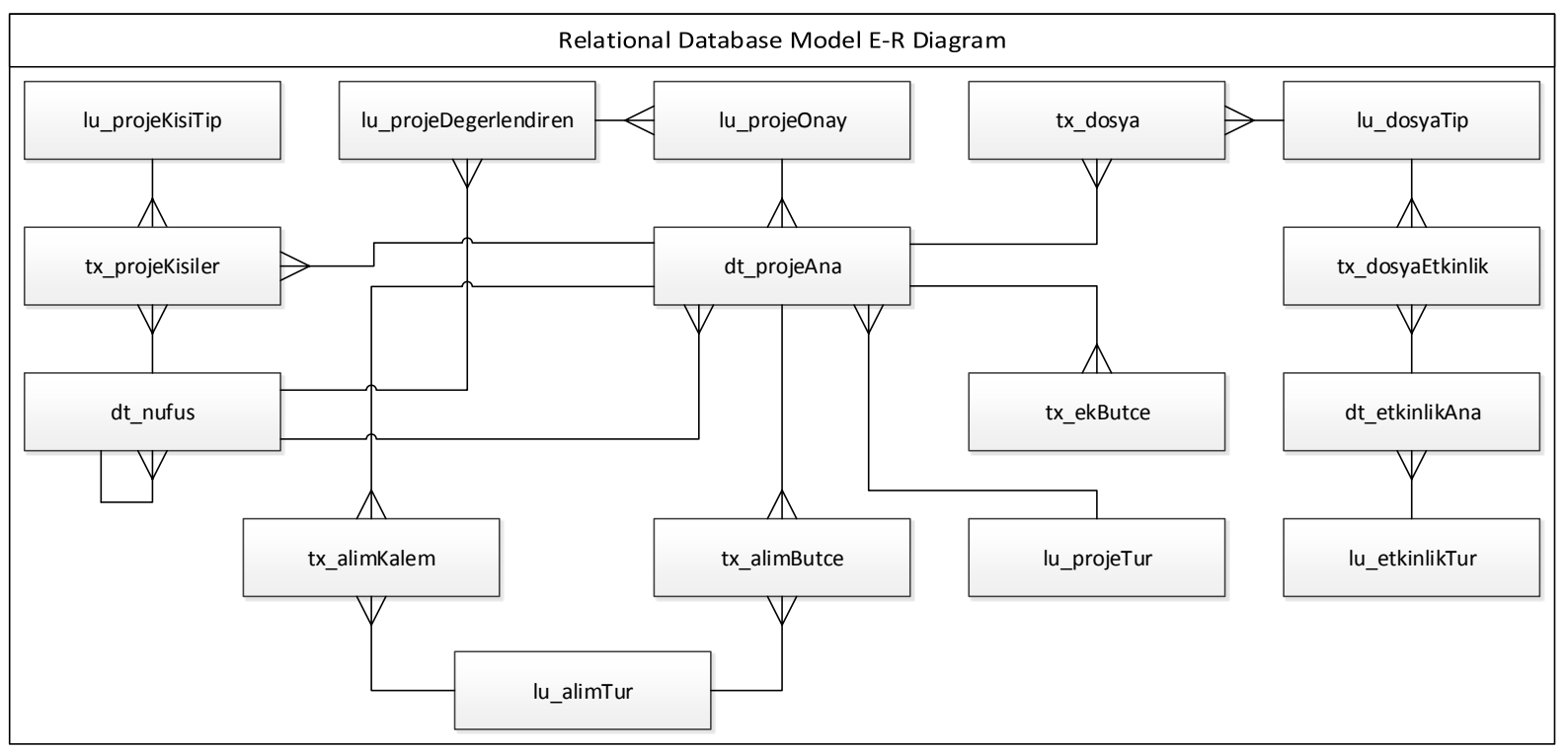

Figure 5. SRP Management Information System Relational Database E-R Diagram

The project application procedure guides users step-by-step with the help of user-friendly interfaces, collects all necessary data in related steps and finally provides a summary report at the last step.

While evaluating a project application, the SRP Coordination Unit takes some criteria such as the requested purchase items, the content and duration of the projects into considiration and makes budget transfers according to the requested purchase items. On the other hand, the Unit uploads progress reports to the system at every 6 months. When the final report is uploaded, the project is closed by the SRP Coordination Unit. At the application stage, distribution reports of current and completed project budgets based on years and departments, as well as expenditures made during the application period for all applications and requested purchase items can be parametrically reported. With the help of these reports, 
it is possible for the university to make future planning and follow current situation analyses as well as performance indicators.

\section{RESULT AND SUGGESTIONS}

The SRP Management Information System for universities has been designed in a way to cover entire processes determined according to regulations and directives for project applications and within the framework of policies specified by the university administration and put into practice. In addition to the SRP Coordination Unit supported projects, external projects, mentor/mentee applications and RFD supported projects have also been included in the scope of the application. Through this application developed within the scope of the study, it is ensured that the processes can be checked online and the procedures can be faster, complete and can be followed. Manual procedures that are carried out traditionally on paper in a difficult, error-prone and slow manner are provided to be easier, error-free and fast. The project managers are allowed to make applications and the SRP Coordination Unit are allowed to follow the entire process in a transparent way through the system. Similarly, it is made possible by the system for online access to notifications, budget processes, statistical data and old-new all project details.

Since the application has been developed according to the PAU SRP Directive as well as the Council of Higher Education (YÖK) in a parametric way, it can easily been adopted to other universities in Turkey. Therefore, in the process of creating reports requested by institutes such as the Scientific and Technological Research Council of Turkey (TÜBITAK) and the Council of Higher Education (YÖK), the necessary indicators can be reported in a transparent way. In this study, it is aimed at making project based performance indicators of universities and academic departments as well as academicians individually, measurable in a complete manner. As a result of the indicators gathered through the application, PAU ascended to rank no. 42 in 2015 from rank no. 48 in 2014 according to Entrepreneurial and Innovative University Index of Turkey (Web-4; Web-5). As a result, PAU has been rapidly rising to a level where it should be in Turkey rankings with the indicators acquired through this application. As is the case with the PAU example, in case of collecting necessary indicators in an effective manner, Turkey will reach the place it deserves among the developed countries. As a matter of fact, Turkey remains very inadequate in terms of research and development indicators as compared to the developed countries (Ünal \& Seçilmiş, 2013).

In addition to e-mail notifications, SMS notifications can also be included in the application for project managers and juries. The jury evaluation process can also be carried out through the system. When YÖKSİS (Higher Education Information System in Turkey) is fully put into use, necessary integration between the two systems, regarding project performances of academicians, can be achieved.

\section{ACKNOWLEDGMENTS}

I would like to thank the employees of PAU Information Technology Department, especially Mehmet Ulaş KOYUNCUOĞLU and Emre ÇAKIR who were assigned in the development and integration of the work, and Veli BAYSAL who is the Branch Manager of SRP Coordination Unit, for participating during the analysis and design of the system. 


\section{REFERENCES}

Altunay, E. \& Tonbul, Y. (2015). Comparison of Scientific Research Projects of Education Faculties. Studies in Higher Education, 40(6), 972-987.

Arifoğlu, A. \& Doğru, A. (2001). Yazılım Mühendisliği: Yöntemler, Metodolojiler, CASE Ortamları, Günün Teknolojisi. SAS Bilişim Yayınları, Ankara.

Britton, C. \& Doake, J. (2005). Software System Development: A Gentle Introduction. McGrawHill, Inc.

Hou, X., Huang, L. \& Li, X. (2015). Evaluation Method of Scientific Research Projects Based on the Neural Networks. In LISS 2013 (pp. 489-496). Springer Berlin Heidelberg.

Leonard, F. J. (2015). The Analysis of the Scientific Research Projects Management in the Higher System of Physical Education. Procedia-Social and Behavioral Sciences, 180, 12481252.

Mezghani, E., Exposito, E. \& Drira, K. (2016). A Collaborative Methodology for Tacit Knowledge Management: Application to Scientific Research. Future Generation Computer Systems, 54, 450-455.

Nastase, G. I. \& Badea, C. G. W. (2015). Aspects Concerning Romanian Scientific Research Funding. Calitatea, 16(S1), 365-368.

Resmi Gazete (2002). Yükseköğretim Kurumları Bilimsel Araştırma Projeleri Hakkında Yönetmelik. 10 Mayıs 2002, Sayı: 24722.

Soares, F. D. S., Soares, D. D. S. \& Arnaud, J. (2014). A Catalog of Information Systems Outsourcing Risks. International Journal of Information Systems and Project Management, $2(3), 23-43$

Tecim, V. \& Gökşen, Y. (2009). Bilişim Teknolojilerinin Üniversitelerde Etkin Kullanımı Üzerine Bir Çalışma. Journal of Yaşar University, 4(14), 2237-2256.

Uçar, E. \& Bilgen, S. (2013). A Case-Based Model for Assessing the Effectiveness of Information Systems Outsourcing. Journal of Information Technology Case and Application Research, 15(3), 27-60.

Ünal, T. \& Seçilmiş, N. (2013). Ar-Ge Göstergeleri Açısından Türkiye ve Gelişmiş Ülkelerle Kıyaslaması. İşletme ve İktisat Çalışmaları Dergisi, 1(1), 12-25.

Wang, Q., Yu, Y. \& Jiang, Y. (2010). Campus Scientific Research management system security and solutions. In Circuits, Communications and System (PACCS), 2010 Second PacificAsia Conference on (Vol. 2, pp. 245-248). IEEE.

Web-1. Yükseköğretim Kurumları Bütçelerinde Bilimsel Araştırma Projeleri İçin Tefrik Edilen Ödeneklerin Özel Hesaba Aktarılarak Kullanımı, Muhasebeleştirilmesi ile Özel Hesabın İşleyişine İlişkin Esas ve Usuller: http://www.bumko.gov.tr/Eklenti/3283,bapesasusulpdf.pdf?0 (15.04.2016)

Web-2. Pamukkale Üniversitesi Bilimsel Araştırma Projeleri (PAÜBAP) Yönergesi: http://www.pau.edu.tr/bap/tr/sayfa/yonerge-pau (15.04.2016) 
Web-3. TÜBİTAK Girişimci ve Yenilikçi Üniversite Endeksi: https://www.tubitak.gov.tr/tr/kurumsal/politikalar/icerik-girisimci-ve-yenilikciuniversite-endeksi (15.04.2016).

Web-4: TÜBİTAK Girişimci ve Yenilikçi Üniversite Endeksi 2014 Sıralaması: http://www.tubitak.gov.tr/sites/default/files/2014_gyue_siralama.pdf (15.04.2016).

Web-5: TÜBİTAK Girişimci ve Yenilikçi Üniversite Endeksi 2015 Sıralaması: http://www.tubitak.gov.tr/sites/default/files/gyue2015_siralama_0.pdf (15.04.2016).

Zhai, J., Li, M. \& Li, J. (2012). Semantic Information Retrieval Based on RDF and Fuzzy Ontology for University Scientific Research Management. In Affective Computing and Intelligent Interaction (pp. 661-668). Springer Berlin Heidelberg. 